\title{
Influence of a novel bm3 corn silage hybrid with floury kernel genetics on lactational performance and feed efficiency of Holstein cows
}

\author{
E. M. Coons, ${ }^{1}$ S. M. Fredin, ${ }^{1}$ K. W. Cotanch, ${ }^{1}$ H. M. Dann, ${ }^{1}$ C. S. Ballard, ${ }^{1}$ J. P. Brouillette, ${ }^{2}$ and R. J. Grant ${ }^{1 *}$ \\ ${ }^{1}$ William H. Miner Agricultural Research Institute, Chazy, NY 12921 \\ ${ }^{2}$ Dow AgroSciences LLC, Indianapolis, IN 46268
}

\section{ABSTRACT}

Dry matter intake, lactation performance, and chewing behavior of multiparous Holstein cows $(n=15)$ fed diets containing a novel $b m 3$ corn silage hybrid with floury kernel genetics were compared with cows fed diets containing commercially available conventional and $b m 3$ hybrids using a replicated $3 \times 3$ Latin square design with 28 -d periods. Cows were housed in tiestalls, milked 3 times/d, and fed a total mixed ration containing $49.0 \%$ (dry matter basis) of (1) a conventional corn silage hybrid (CONV); (2) a brown midrib bm3 hybrid (BMR); or (3) a bm3 hybrid with floury kernel genetics (BMRFL). All diets contained $6.3 \%$ hay crop silage and $44.7 \%$ concentrate. Dietary nutrient composition averaged $32.7 \%$ neutral detergent fiber (NDF) and 26.3 starch (\% of dry matter). Data were analyzed by ANOVA using the MIXED procedure in SAS (SAS Institute Inc., Cary, NC). The dry matter intake was greater for cows fed BMR $(28.0 \mathrm{~kg} / \mathrm{d})$ compared with CONV (26.8 $\mathrm{kg} / \mathrm{d}$ ), whereas dry matter intake for cows fed BMRFL was intermediate $(27.6 \mathrm{~kg} / \mathrm{d})$. Energy-corrected milk (ECM) yield was greater for cows fed BMR $(50.3 \mathrm{~kg} / \mathrm{d})$ and BMRFL $(51.8 \mathrm{~kg} / \mathrm{d})$ compared with CONV (47.2 $\mathrm{kg} / \mathrm{d}$ ). Milk fat yield was higher for cows fed BMRFL $(1.87 \mathrm{~kg} / \mathrm{d})$ compared with CONV $(1.74 \mathrm{~kg} / \mathrm{d})$ and BMR $(1.80 \mathrm{~kg} / \mathrm{d})$. Milk protein yield was greater for cows fed BMR $(1.49 \mathrm{~kg} / \mathrm{d})$ and BMRFL $(1.54 \mathrm{~kg} / \mathrm{d})$ compared with CONV $(1.36 \mathrm{~kg} / \mathrm{d})$. Milk urea-N was reduced for cows fed BMR (11.61 mg/dL) and BMRFL $(11.16 \mathrm{mg} / \mathrm{dL})$ compared with CONV $(13.60 \mathrm{mg} / \mathrm{dL})$. Feed efficiency (ECM/dry matter intake) was higher for cows fed BMRFL (1.87) compared with CONV (1.76) and BMR (1.79). Milk $\mathrm{N}$ efficiency was greatest for cows fed BMRFL (40.4\%) followed by BMR (38.1\%) and finally CONV (35.3\%). Cows fed CONV chewed 5 min more per kilograms of NDF consumed than cows fed either of the BMR hybrids. No differences were ob-

Received April 11, 2019.

Accepted June 28, 2019

*Corresponding author: grant@whminer.com served among diets in apparent total-tract digestibility of NDF $(58.1 \%)$ or starch $(99.3 \%)$. Overall lactational performance was enhanced for cows fed diets containing both BMR and BMRFL hybrids versus CONV. In addition, feeding the BMRFL corn silage improved efficiency of component-corrected milk production and milk $\mathrm{N}$ efficiency compared with the CONV and BMR silages.

Key words: brown midrib, floury corn, feed efficiency, dairy cattle

\section{INTRODUCTION}

High-producing dairy cows require a complex balance of fermentable carbohydrates and highly digestible forages to promote ruminal health, greater DMI, and high milk component yields. Fiber digestibility and gut fill limit production capabilities of dairy cattle fed highforage diets (Allen, 2000). Brown midrib (bm3) corn silage (CS) often contains less lignin than conventional CS, resulting in higher NDF digestibility and enabling greater DMI before gut fill is achieved (Ebling and Kung, 2004). However, starch digestibility is commonly reported to be lower for diets containing bm3 CS than for diets containing conventional CS. For example, Ferraretto and Shaver (2015) observed a 6-percentage-unit decrease in ruminal starch digestibility and a 1.4-percentage-unit decrease in total-tract starch digestibility for cows fed bm3 CS compared with conventional CS. The reduced starch digestibility for diets containing bm3 CS may be related to faster passage rate of digesta due to increased DMI (Moharrery et al., 2014). In addition, reduced starch digestibility may also be related to greater kernel vitreousness of some bm3 CS hybrids compared with other commercially available CS hybrids (Ferraretto and Shaver, 2015).

Corn hybrids carrying floury kernel mutations, such as the FL2 allele, have less kernel zein protein and higher ruminal and total-tract starch digestibility (Lopes et al., 2009). Zein protein cross-links and surrounds starch granules in the endosperm, thereby preventing rumen microbial enzymatic degradation of starch 
(Hoffman et al., 2011; Giuberti et al., 2014). Taylor and Allen (2005b) reported a $63 \%$ increase in ruminal starch digestion for diets containing floury corn grain compared with diets containing vitreous corn. Similar responses in starch digestion have not been observed when corn was harvested at silage rather than grain moisture content. However, Longuski et al. (2002) did observe a trend toward increased efficiency of FCM production with floury versus vitreous endosperm corn silage. Consequently, a CS hybrid with improved NDF and starch digestibility may be expected to support greater milk and component yields and result in greater feed efficiency for high-producing dairy cows than a bm3 hybrid.

The objective of this experiment was to compare diets containing a novel bm 3 CS hybrid with floury kernel genetics (i.e., FL2) to diets containing commercially available conventional and bm3 CS hybrids for their effects on DMI, lactational performance, chewing behavior, and total-tract nutrient digestibility of Holstein cows. We hypothesized that cows fed either of the bm3 CS hybrids would have greater DMI and lactational performance compared with cows fed the conventional CS hybrid. We further hypothesized that the experimental bm3 CS hybrid with softer endosperm would supply more digestible energy through improved starch digestion compared with the conventional and bm3 CS hybrids, resulting in increased milk component yields and feed efficiency.

\section{MATERIALS AND METHODS}

\section{Corn Silage Production}

Three corn hybrids [Mycogen TMF2R447 (tall SmartStax hybrid with medium ear placement), 98-d relative maturity; Mycogen F2F498, 99-d relative maturity; and Mycogen FBDAS3 (floury FL2, bm3, Dow AgriSciences, and SmartStax selection) trademarked as Unified hybrid with SilaSoft floury kernel mutation, 96-d relative maturity, Mycogen Seeds, Dow AgroSciences LLC, Indianapolis, IN] were planted in a 6.07-ha field at the William H. Miner Agricultural Research Institute (Chazy, NY) on May 31, 2014, with 76-cm row spacing and 84,000 seeds/ha. The Mycogen FBDAS3 hybrid contained FL2 genetics. The relative effect of floury corn genetics (FL2) versus flint and dent genetics on nutrient composition, and reduced zein content particularly, has been reported by Larson and Hoffman (2008). Zein content has been shown to be negatively related to corn endosperm softness (Dombrink-Kurtzman and Beitz, 1993).

Plots were separated by a buffer strip of a commercially available CS hybrid (Mycogen 2H079, 79-d relative maturity). All 3 plots were managed under the same tillage, fertilizer, and weed control procedures. Areas harvested were 1.32, 1.38, and 2.10 ha for TMF2R447, F2F498, and FBDAS3, respectively. Field plots were harvested using a self-propelled forage harvester with a kernel-processing unit (model 7300, John Deere, Moline, IL) with a 20.3-cm cut height, a $19-\mathrm{mm}$ theoretical length of cut, and 3-mm roller gap spacing. Plots were harvested when kernel maturity reached 1/4-milk line on October 7, 2014. Each CS hybrid was inoculated with Biotal Buchneri 500 (Lallemand Animal Nutrition, Milwaukee, WI) and stored in separate $2.7-\times 30.5-\mathrm{m}$ silage bags (AG-BAG plastic, Cottage Grove, MN) until the start of the feeding experiment. Average yields were $11.8,12.5$, and $10.6 \mathrm{t}$ of $\mathrm{DM} / \mathrm{ha}$ for the TMF2R447, F2F498, and FBDAS3 CS hybrids, respectively.

\section{Experimental Design, Diets, and Management of Cows}

The feeding experiment was conducted at the William H. Miner Agricultural Research Institute from January 30 to April 23, 2015, with environmental temperatures ranging from -7 to $21^{\circ} \mathrm{C}\left(6.7^{\circ} \mathrm{C} \pm 3.2\right.$; mean $\left.\pm \mathrm{SD}\right)$ and relative humidity (\%) ranging from 23 to $92(68$ \pm 12 ; mean $\pm \mathrm{SD}$ ). All procedures involving animals were approved by the William H. Miner Agricultural Research Institute Animal Care and Use Committee. Fifteen multiparous Holstein cows were blocked by $3.5 \%$ FCM and assigned randomly to 1 of 3 squares using a replicated $3 \times 3$ Latin square design with 28 -d periods with all squares conducted concurrently. The first $21 \mathrm{~d}$ served as the dietary adaptation period and the last $7 \mathrm{~d}$ served as the collection period. Cows averaged (mean \pm SD) $682 \pm 59 \mathrm{~kg}$ of BW, $112 \pm 13 \mathrm{DIM}$, and $2.4 \pm 0.7$ lactations at the beginning of the experiment.

Cows were fed a diet containing $49.1 \%$ CS with 3 dietary treatments formulated for a 1-to-1 replacement of CS: (1) conventional TMF2R447 (CONV), (2) F2F498 bm3 (BMR), or (3) experimental FBDAS3 bm3 hybrid with floury kernel genetics (Unified with SilaSoft kernel mutation, FL2 genetics; BMRFL). Ingredient composition of the 3 dietary treatments is provided in Table 1. Diets were formulated with the Nutritional Dynamic System model (RUM\&N Sas, version 3.8.8.10, Via Sant'Ambrogio, Italy) utilizing the Cornell Net Carbohydrate and Protein System (version 6.5, Cornell University, Ithaca, NY). Diets were formulated using the description for a 3rd lactation cow, 119 DIM with a BCS of 3.0, mature BW of $726 \mathrm{~kg}$, and milk yield of 45 $\mathrm{kg}$ containing $3.8 \%$ fat and $3.2 \%$ true protein.

Cows were housed in a tiestall barn on mattresses bedded with sawdust with individual feed boxes and 
Table 1. Ingredient composition (\% of DM) of the diets

\begin{tabular}{|c|c|c|c|}
\hline \multirow[b]{2}{*}{ Item } & \multicolumn{3}{|c|}{ Diet $^{1}$} \\
\hline & CONV & BMR & BMRFL \\
\hline TMF2R447 corn silage & 48.99 & - & - \\
\hline F2F498 corn silage & - & 48.99 & - \\
\hline FBDAS3 corn silage & - & - & 48.99 \\
\hline Hay crop silage & 6.32 & 6.32 & 6.32 \\
\hline \multicolumn{4}{|l|}{ Grain mix } \\
\hline Ground corn grain & 13.91 & 13.91 & 13.91 \\
\hline Beet pulp pellets & 7.26 & 7.26 & 7.26 \\
\hline Canola meal & 6.41 & 6.41 & 6.41 \\
\hline Soybean meal, solvent extracted & 5.69 & 5.69 & 5.69 \\
\hline Soybean meal, heat-treated ${ }^{2}$ & 4.17 & 4.17 & 4.17 \\
\hline Rumen inert fat ${ }^{3}$ & 2.13 & 2.13 & 2.13 \\
\hline Molasses & 1.15 & 1.15 & 1.15 \\
\hline Blood meal & 1.07 & 1.07 & 1.07 \\
\hline Calcium carbonate & 0.99 & 0.99 & 0.99 \\
\hline Sodium sesquicarbonate $^{4}$ & 0.79 & 0.79 & 0.79 \\
\hline Salt & 0.39 & 0.39 & 0.39 \\
\hline Magnesium oxide & 0.28 & 0.28 & 0.28 \\
\hline Urea & 0.19 & 0.19 & 0.19 \\
\hline Methionine $^{5}$ & 0.11 & 0.11 & 0.11 \\
\hline Yeast and organic selenium ${ }^{6}$ & 0.09 & 0.09 & 0.09 \\
\hline Vitamins $\mathrm{A}, \mathrm{D}$, and $\mathrm{E}^{7}$ & 0.03 & 0.03 & 0.03 \\
\hline Organic minerals ${ }^{8}$ & 0.01 & 0.01 & 0.01 \\
\hline Vitamin $\mathrm{E}^{9}$ & 0.01 & 0.01 & 0.01 \\
\hline Monensin $^{10}$ & 0.01 & 0.01 & 0.01 \\
\hline
\end{tabular}

${ }^{1} \mathrm{CONV}=$ diet containing TMF2R447 (Dow AgroSciences LLC, Indianapolis, IN), a conventional corn silage; BMR = diet containing F2F498 (Dow AgroSciences LLC), a bm3 corn silage; BMRFL = diet containing FBDAS3 (Dow AgroSciences LLC), a bm3 corn silage with floury kernel genetics.

${ }^{2}$ Amino Plus, Ag Processing Inc., Omaha, NE.

${ }^{3}$ BergaFat, Berg + Schmidt America LLC, Libertyville, IL.

${ }^{4} \mathrm{~S}-\mathrm{Carb}, \mathrm{FCM}$ Industrial Chemical Group, Philadelphia, PA.

${ }^{5}$ MetaSmart, Adisseo USA Inc., Alpharetta, GA.

${ }^{6}$ Diamune, Diamond V Mills Inc., Cedar Rapids, IA.

${ }^{7}$ Contained $24,093 \mathrm{kIU}$ of vitamin $\mathrm{A} / \mathrm{kg}, 5,552 \mathrm{kIU}$ of vitamin $\mathrm{D} / \mathrm{kg}$, and $92,676 \mathrm{IU}$ of vitamin $\mathrm{E} / \mathrm{kg}$.

${ }^{8}$ Availa 4, Zinpro Co., Eden Prairie, MN.

${ }^{9}$ Contained 89,985 IU of vitamin E/ $\mathrm{kg}$.

${ }^{10}$ Elanco Animal Health, Greenfield, IN.

water bowls. Cows were fed for ad libitum intake (targeted refusal rate of 10\%) once daily at $1300 \mathrm{~h}$; feed was pushed up at $0730 \mathrm{~h}$. The dietary treatments were prepared in a Calan Data Ranger (American Calan Inc., Northwood, NH). Cows were milked 3 times daily $(0430,1230$, and $2030 \mathrm{~h})$ in a double-12 parallel milking parlor (Xpressway Parallel Stall System, BouMatic, Madison, WI).

\section{Data Collection, Sample Procedures, and Analytical Methods}

Individual feed ingredients were collected weekly and dried in a forced-air oven at $55^{\circ} \mathrm{C}$ for $24 \mathrm{~h}$ for $\mathrm{DM}$ determination. Diets were adjusted for changes in the $\mathrm{DM}$ content of the feed ingredients when the DM of an ingredient varied by $1.2 \mathrm{SD}$ from the mean DM. Feed ingredients, diets, and orts were collected daily on d 22 to 28 of each period and dried in a forced-air oven at $105^{\circ} \mathrm{C}$ for $24 \mathrm{~h}$ for $\mathrm{DM}$ determination. The remainder of each sample was frozen at $-20^{\circ} \mathrm{C}$ and composited by period on an equal volume basis for chemical analysis.

Composites of feed ingredients, diets, and orts were analyzed for chemical composition by a commercial laboratory (Cumberland Valley Analytical Services Inc., Waynesboro, PA). Analyses included DM (high volume, low temperature method), ash (method 942.05; AOAC International, 2012), OM (method 942.05; AOAC International, 2012), CP (method 990.03; AOAC International, 2012), soluble protein according to Krishnamoorthy et al. (1982), fat (method 2003.05; AOAC International, 2012), ADF (method 973.18; AOAC International, 2012), NDF using $\alpha$-amylase (Van Soest et al., 1991), ADL (Goering and Van Soest, 1970), starch according to Hall (2009), sugar as ethanol-soluble carbohydrates according to Dubois et al. (1956), and minerals (method 985.01; AOAC International, 2012).

Fermentation analysis was performed on the ensiled forage composite samples (Cumberland Valley Analytical Services Inc., Waynesboro, PA). A 25-g wet sample was diluted with $200 \mathrm{~mL}$ of water, blended, and filtered through 20- to $25-\mu \mathrm{m}$ filter paper. Extract was used to determine $\mathrm{pH}$ with a Mettler DL12 $\mathrm{pH}$ Titrator (Mettler-Toledo LLC, Columbus, $\mathrm{OH}$ ) and $\mathrm{NH}_{3}-\mathrm{N}$ in a 1-to-3 ratio of extract and water with a Labconco Rapidstill II model 65200 analyzer (Labconco, Kansas City, $\mathrm{MO})$. Lactic acid was determined in a 1-to-1 ratio of extract and water with a YSI 2700 Select Biochemistry Analyzer (YSI Inc., Yellow Springs, OH). This method determines L-lactate, which is multiplied by 2 to provide a measure of lactic acid. Acetic, propionic, butyric, and isobutyric acid concentrations were determined with a Perkin Elmer AutoSystem gas chromatograph using a Restek column packed with Stabilwax-DA (Perkin Elmer, Shelton, CT).

Forage and dietary composite samples were used to determine particle size distribution on an as-fed basis using the Penn State Particle Separator (Lammers et al., 1996) with 19-, 8-, and 4-mm screens. Particle size distribution was also determined on forages, grain mix, and diets on a $\mathrm{DM}$ basis $\left(55^{\circ} \mathrm{C}\right)$ by dry vertical sieving (Ro-Tap testing sieve shaker model B; W. S. Tyler Combustion Engineering Inc., Mentor, $\mathrm{OH}$ ) with 19.0-, 13.2-, 9.5-, 6.7-, 4.75-, 3.35-, 2.36-, 1.18-, 0.60-, and $0.30-\mathrm{mm}$ sieves for $10 \mathrm{~min}$. The physical effectiveness factor (pef) was determined by the standard dry vertical sieving method for feed ingredients and diets (Mertens, 2002). Physically effective NDF (peNDF) of a feed ingredient or diet was calculated as the product 
of its NDF content and its pef value (\% of DM $>1.18$ mm; adapted from Mertens, 1997).

Undigested NDF for 30-, 120-, and 240-h time points for forage composite samples were analyzed using the Tilley-Terry rumen fermentation system (Raffrenato et al., 2019). Neutral detergent fiber with residual ash, using $\alpha$-amylase and sodium sulfite (Van Soest et al., 1991), was determined by the Ankom A200 Fiber Analyzer filter bag technique (Ankom Technology Corp., Fairpoint, NY). Ruminal in vitro digestibility of starch (2- and 7-h incubation) of grain mixes, diets, and CS ground to pass a 4-mm screen using a Wiley mill was determined (Cumberland Valley Analytical Services Inc., Waynesboro, PA) according to Richards et al. (1995). Additionally, all 3 CS hybrids were analyzed for the fast pool rate $(\mathrm{kd} / \mathrm{h})$ of nutrient digestion, slow pool rate $(\mathrm{kd} / \mathrm{h})$ of nutrient digestion, the carbohydrate $\mathrm{B}_{1}$ and $\mathrm{B}_{3}$ rates $(\% / \mathrm{h})$ specific to the Cornell Net Carbohydrate and Protein System, and microbial biomass production (mg/g; Fermentrics; RFS Technologies, Ottawa, ON, Canada; samples submitted to Dairyland Labs Inc., Arcadia, WI) according to Dairyland Laboratories Inc. (2013), which was developed from previously published in vitro gas production systems (Schofield and Pell, 1995; Blummel et al., 1997).

Body weight was measured (Allweigh computerized scale, Allweigh Scale System Inc., Red Deer, AB, Canada) and BCS was assigned in 0.25-unit increments on a 1-to-5 scale (Ferguson et al., 1994) for each cow after the $1230 \mathrm{~h}$ milking at the beginning of the experiment and on $\mathrm{d} 28$ of each period.

Dry matter intake was determined by recording feed offered and refused daily on d 22 to 28 for each cow during each period. Dry matter content (described previously) was determined for diets and orts on d 22 to 28 and used to calculate DMI.

Milk yields were recorded (ProVantage Information Management System, BouMatic) at every milking from d 22 to 28 of each period and used to calculate average daily yield. Milk samples from 3 consecutive milkings per $\mathrm{d}$ for each cow were collected on d 25 and 26 of each test period, preserved (Bronolab-W II Liquid Preservative, D \& F Control Systems Inc., Dublin, CA), and stored at $4^{\circ} \mathrm{C}$. Milk samples were sent to a commercial laboratory (Dairy One, Ithaca, NY), and analyzed for fat, true protein, lactose, SNF, and MUN (method 972.16; AOAC International, 2012), and SCC (Foss 4000, Foss Technology, Eden Prairie, MN). Samples were mathematically composited by day in proportion to milk yield at each sampling. Somatic cell count was transformed and analyzed as SCS according to Shook (1993) using the equation: $\mathrm{SCS}=\log _{2}(\mathrm{SCC} / 100)+3$, where SCC is in units of 1,000 cells $/ \mathrm{mL}$. Milk (average of d 22 to 28), fat, true protein, and SNF yields (aver- age of d 25 and 26 ) were used to calculate $3.5 \%$ FCM using the equation: $3.5 \% \mathrm{FCM}=[(0.432 \times \mathrm{kg}$ of milk yield $)+(16.216 \times \mathrm{kg}$ of fat yield $)]$ SCM using the equation: $\mathrm{SCM}=[(12.3 \times \mathrm{kg}$ of fat yield $)+(6.56 \times \mathrm{kg}$ of SNF) $-(0.0752 \times \mathrm{kg}$ of milk yield $)]$; and ECM using the equation: $\mathrm{ECM}=[(0.327 \times \mathrm{kg}$ of milk yield $)+$ $(12.95 \times \mathrm{kg}$ of fat yield $)+(7.65 \times \mathrm{kg}$ of protein yield $)]$ according to Tyrrell and Reid (1965).

Feed efficiency $(\mathrm{kg} / \mathrm{kg})$ was calculated and expressed as actual milk/DMI, 3.5\% FCM/DMI, and SCM/DMI for d 25 through 26 of each period. Milk N efficiency was calculated as $(\mathrm{kg}$ of milk $\mathrm{N} / \mathrm{kg}$ of $\mathrm{N}$ intake $) \times 100$.

Cows were monitored for eating, rumination, and chewing (eating + rumination) behavior every $5 \mathrm{~min}$ for 2 consecutive 24-h blocks (d 25 to 26 ) each period. Observations were averaged to create one 24 -h observation per cow per period.

Apparent total-tract nutrient digestibility was determined from fecal grab samples collected on d 25 to 28 of each period so that every $3 \mathrm{~h}$ in a 24 -h time period were represented. Fecal samples of each cow were composited by combining $118 \mathrm{~mL}$ (wet basis) of manure from each time period $(\mathrm{n}=8)$. Fecal samples were stored at $-20^{\circ} \mathrm{C}$, dried in a forced-air oven at $55^{\circ} \mathrm{C}$ for $72 \mathrm{~h}$, and ground to pass through a $1-\mathrm{mm}$ screen (Wiley mill, Arthur H. Thomas, Philadelphia, PA). Composite samples of diets (by period), orts (by cow), and feces (by cow) were analyzed for DM, NDF, starch, and $\mathrm{OM}$ as described above. Undigested ash-free NDF (uNDFom) was determined after a 240-h ruminal in vitro fermentation (Ankom Technology Corp., Fairport, NY) in buffered ruminal medium (Goering and Van Soest, 1970) and was used as an internal marker in the diets, orts, and feces. Total-tract nutrient digestibility was calculated by the ratio technique using the concentrations of the nutrients and uNDFom (internal marker) in the diet and feces (Maynard et al., 1979). The nutrient content of the diet used in the digestibility calculation was adjusted for each cow based on the nutrient composition of the diet offered and refused using the equation: apparent total-tract nutrient digestibility $(\%)=100-[100 \times($ TMR uNDFom content/fecal uNDFom content $) \times($ fecal nutrient content/diet nutrient content)].

\section{Starch Digestibility Measured Using Mini-Silos}

To better understand how starch digestibility might change over time of ensiling, FoodSaver vacuum-sealed bags (Sunbeam Products, Boca Raton, FL) were filled on the day of harvest for the lactation study with approximately $800 \mathrm{~g}$ of forage $(\mathrm{n}=6 /$ time point $)$ and sealed. After sealing, all bags were stored at a constant temperature of $20^{\circ} \mathrm{C}$. 
At each ensiling time point $(30,60,90$, and $120 \mathrm{~d})$, bags were opened and contents of each bag were mixed thoroughly. Sub-samples were analyzed for 7-h starch digestibility as previously described.

\section{Statistical Analysis}

Statistical analysis was performed using SAS (version 9.2, SAS Institute Inc., Cary, NC). Data from the analysis of feed ingredients and diets were analyzed using the MEANS procedure of SAS ( $\mathrm{n}=3$ per feed ingredient and diet). The data were reported as descriptive statistics (mean $\pm \mathrm{SE}$ ). The experiment was conducted and analyzed as a Latin square design. Data collected over time (i.e., DMI, milk yield and composition, and behavior) were reduced to a period mean per cow. Data were subjected to ANOVA using the MIXED procedure of SAS. Fixed effects were treatment, period, square, and the treatment $\times$ square interaction. Cow nested within square was considered a random effect. The starch digestibility data from the mini-silo samples were analyzed as a completely randomized design in a $5 \times 3$ factorial arrangement of treatments using the MIXED procedure of SAS with ensiling time, hybrid, and time $\times$ hybrid as fixed effects. Mini-silo was used as the experimental unit.

Least squares means from the ANOVA results were separated using the Tukey procedure when the resulting $F$-test was $P \leq 0.05$. Significance was declared at $P$ $\leq 0.05$ and tendencies at $0.05<P \leq 0.10$.

\section{RESULTS AND DISCUSSION}

\section{Dietary and Ingredient Nutrient Composition}

Chemical composition and in vitro NDF and starch digestibility of the ingredients included in the diets are presented in Table 2. Neutral detergent fiber content averaged 42.9, 40.6, and 39.7\% for CONV, BMR, and BMRFL hybrids, respectively. Starch content averaged $30.2,30.2$, and $32.2 \%$ for CONV, BMR, and BMRFL hybrids, respectively. As expected, uNDFom was numerically greater at all fermentation time points for CONV compared with BMR and BMRFL hybrids resulting in higher NDF digestibility (\% of NDF) for BMR and BMRFL compared with CONV. Unexpectedly, the digestibility of starch determined after 2- and 7-h ruminal in vitro incubations was similar among CS hybrids, averaging 28.5 and $80.1 \%$, respectively. With Fermentrics analysis, the fast pool of nutrient digestion was $25.1,37.7$, and $36.7 \% / \mathrm{h}$ for the CONV, BMR, and BMRFL CS hybrids, respectively. With this system, the fast pool digestion rate is derived from the maximal kd per hour of silage acids, sugars, rapidly degraded starch, soluble fiber, and very rapidly digesting NDF (Dairyland Laboratories Inc., 2013). Although the differences were small (and not statistically analyzed) among the CS hybrids in starch digestion rate (B1 fraction), the rates increased slightly from CONV to BMR to BMRFL (Table 2). Microbial biomass production was greater for the BMRFL hybrid $(147.0 \mathrm{mg} / \mathrm{g})$ compared with CONV (125.2 mg/g) and BMR (138.3 $\mathrm{mg} / \mathrm{g}$ ), suggesting greater ruminal carbohydrate digestibility and increased microbial protein synthesis for cows fed the BMRFL hybrid. These differences among the 3 CS hybrids in microbial biomass agree reasonably well with the observed milk production responses.

The particle size distributions (as-fed basis) of all 3 CS hybrids, presented in Table 3, were similar when assessed by the Penn State Particle Separator and RoTap shaker method (DM basis).

Effect of hybrid and ensiling time on in vitro starch digestibility (ivSD) from mini-silos is shown in Figure 1. A hybrid $\times$ ensiling time interaction was observed for ivSD $(P=0.02$; Figure 1$)$; ivSD was greater for CONV than other hybrids $(70.1$ vs. $65.5 \%$ of starch, on average) on $0 \mathrm{~d}$, similar among hybrids from 30 to $90 \mathrm{~d}$, and greater for BMRFL than other hybrids ( 80.3 vs. $74.7 \%$ of starch, on average) after $120 \mathrm{~d}$ of fermentation. Although this is the first report to our knowledge evaluating a bm3 hybrid with floury kernel characteristics, differences in starch digestibility among hybrids with varying kernel characteristics after 120 or $240 \mathrm{~d}$ in storage was previously reported (Ferraretto et al., 2015b,c). These data suggest that perhaps instead of decreasing, ensiling time may increase the difference in starch digestibility among hybrids of varied kernel endosperm characteristics. We do not have an explanation for why the observed starch digestibility responses differed between the mini-silo system and the larger scale bunker silos used for the feeding study; it is possible that different fermentations occurred within each silo system and may have affected starch digestibility.

Chemical composition and starch digestibility of the diets are presented in Table 4. The content of NDF, starch, and 7-h starch digestibility were similar across the 3 diets and averaged $32.7,26.3$, and $77.7 \%$, respectively. Particle size distribution of the diets is presented in Table 5. Particle distribution (as-fed basis) based on the Penn State Particle Separator (DM basis) was consistent across all diets with an average pef and peNDF value of 0.69 and $22.2 \%$, respectively.

Overall, we concluded that peNDF did not contribute to any observed differences among diets. There were clear advantages in NDF digestibility for the BMR and BMRFL silages versus the CONV. Although the 7-h ivSD assay was unable to differentiate among the CS hybrids and their respective diets, we concluded that 
Table 2. Chemical composition, in vitro digestibility, and fermentation analysis (mean $\pm \mathrm{SE}$ ) of ingredients used in the diets ${ }^{1}$

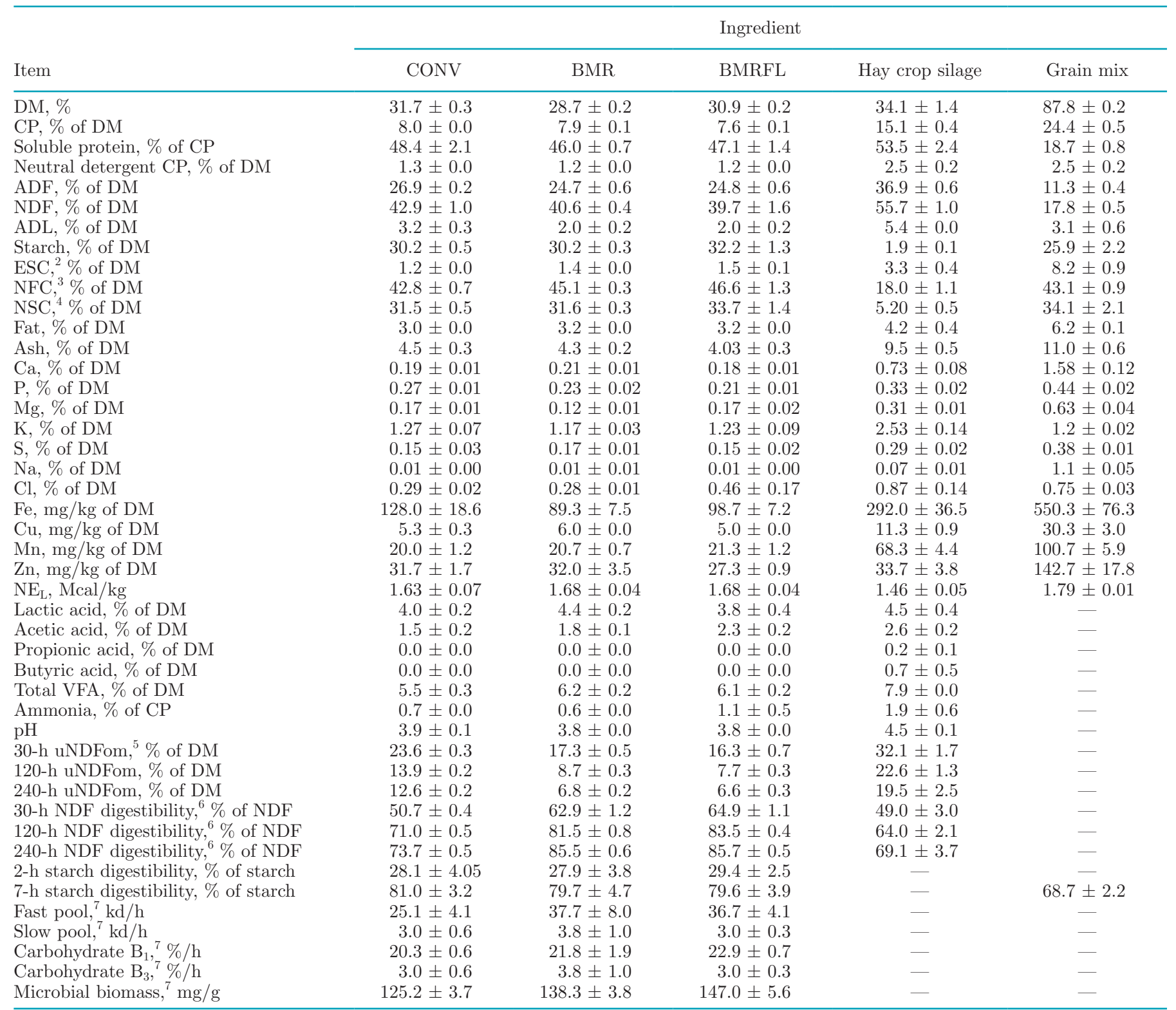

${ }^{1} \mathrm{CONV}=$ diet containing TMF2R447 (Dow AgroSciences LLC, Indianapolis, IN), a conventional corn silage; BMR = diet containing F2F498 (Dow AgroSciences LLC), a bm3 corn silage; BMRFL = diet containing FBDAS3 (Dow AgroSciences LLC), a bm3 corn silage with floury kernel genetics.

${ }^{2} \mathrm{ESC}=$ ethanol-soluble carbohydrate.

${ }^{3} \mathrm{NFC}=100-[\mathrm{CP} \%+(\mathrm{NDF} \%-$ neutral detergent insoluble $\mathrm{CP} \%)+$ fat $\%+\operatorname{ash} \%] ;$ NRC $(2001)$.

${ }^{4} \mathrm{NSC}=$ starch + ESC.

${ }^{5} \mathrm{uNDFom}=$ undigested ash-free NDF.

${ }^{6} \mathrm{NDF}$ with residual ash using $\alpha$-amylase and sodium sulfite.

${ }^{7}$ Fast pool, slow pool, carbohydrate $\mathrm{B}_{1}$ and $\mathrm{B}_{3}$ rate, and microbial biomass were analyzed by Fermentrics (RFS Technologies, Ottawa, ON, Canada).

the greater starch digestibility for the BMRFL at 120 $\mathrm{d}$ ensiling (which coincided with the time frame of the lactation study) and the greater microbial biomass production reflected greater ruminal carbohydrate digestibility (NDF and starch) for the BMRFL silage com- pared with the BMR and CONV silages. Also, a small difference (1.4 percentage units) was observed among the 3 diets in total starch content, and it is possible that this range in starch contributed to the differences among diets in ruminal carbohydrate digestibility and 


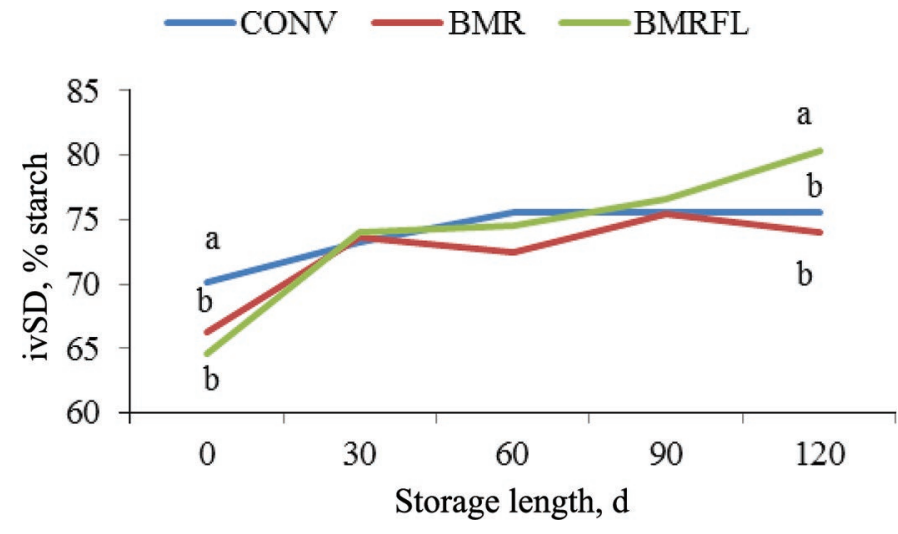

Figure 1. Interaction between storage length and hybrid for ruminal in vitro starch digestibility at $7 \mathrm{~h}$ (ivSD; $P=0.02$; SEM $=$ 1.19). Treatments were conventional (CONV), brown midrib containing the $b m 3$ gene mutation (BMR), or BMR containing the FL2 allele (BMRFL) hybrid ensiled from 0 to $120 \mathrm{~d}$. Data points at a specific storage length indicated with unlike lowercase letters $(\mathrm{a}, \mathrm{b})$ differ $(P$ $<0.05)$. some of the observed differences in cow response to diets.

\section{Dry Matter and Nutrient Intake}

Dry matter and nutrient intake, BW, and BCS are summarized in Table 6. Dry matter intake was greater for cows consuming BMR $(28.0 \mathrm{~kg} / \mathrm{d}$ and $4.03 \%)$ compared with CONV $(26.8 \mathrm{~kg} / \mathrm{d}$ and $3.87 \% ; P=0.01$ and $P<0.01)$. Dry matter intake for cows consuming BMRFL was intermediate $(27.6 \mathrm{~kg} / \mathrm{d}$ and $3.94 \%)$. Holt et al. (2013a) found that cows between 60 and 180 DIM fed a bm3 CS diet consumed approximately $1 \mathrm{~kg} / \mathrm{d}$ more than cows fed a conventional CS diet, likely due to reduced gut fill for cows consuming bm3. Similarly, Ferraretto and Shaver (2015) reported a $0.9 \mathrm{~kg} / \mathrm{d}$ increase in DMI for cows consuming BMR, most likely related to increased NDF digestibility and rumen passage rate. In contrast to NDF digestibility, Taylor and Allen (2005a) reported no effect of grain endosperm type on DMI of lactating cows fed diets containing floury or vitreous endosperm corn.

Table 3. Particle size (mean $\pm \mathrm{SE}$ ) characterizing the physical form of ingredients used in the diets ${ }^{1,2}$

\begin{tabular}{|c|c|c|c|c|c|}
\hline \multirow[b]{2}{*}{ Item } & \multicolumn{5}{|c|}{ Ingredient } \\
\hline & $\mathrm{CONV}$ & BMR & BMRFL & Hay crop silage & Grain mix \\
\hline$>19.0 \mathrm{~mm}$ & $1.4 \pm 0.1$ & $1.0 \pm 0.1$ & $2.6 \pm 0.5$ & $38.9 \pm 3.9$ & - \\
\hline 8.0 to $19.0 \mathrm{~mm}$ & $79.6 \pm 0.4$ & $77.6 \pm 0.2$ & $80.4 \pm 0.7$ & $39.6 \pm 1.7$ & - \\
\hline 4.0 to $8.0 \mathrm{~mm}$ & $12.1 \pm 0.2$ & $13.0 \pm 0.3$ & $11.1 \pm 0.4$ & $13.9 \pm 2.0$ & - \\
\hline$<4.0 \mathrm{~mm}$ & $6.9 \pm 0.2$ & $8.3 \pm 0.1$ & $5.9 \pm 0.2$ & $7.5 \pm 0.4$ & - \\
\hline \multicolumn{6}{|c|}{ Particle size distribution, ${ }^{6} \%$ of DM } \\
\hline$>19.00 \mathrm{~mm}$ & $0.1 \pm 0.7$ & $0.1 \pm 0.1$ & $0.0 \pm 0.0$ & $1.6 \pm 1.2$ & $0.0 \pm 0.0$ \\
\hline 13.20 to $19.00 \mathrm{~mm}$ & $0.3 \pm 0.1$ & $0.1 \pm 0.1$ & $0.3 \pm 0.2$ & $1.0 \pm 0.6$ & $0.0 \pm 0.0$ \\
\hline 9.50 to $13.20 \mathrm{~mm}$ & $3.4 \pm 0.4$ & $2.9 \pm 0.2$ & $3.8 \pm 0.3$ & $1.2 \pm 0.2$ & $0.8 \pm 0.4$ \\
\hline 6.70 to $9.50 \mathrm{~mm}$ & $13.4 \pm 1.1$ & $13.1 \pm 0.6$ & $17.2 \pm 0.6$ & $3.2 \pm 0.6$ & $21.5 \pm 3.3$ \\
\hline 4.75 to $6.70 \mathrm{~mm}$ & $18.2 \pm 0.7$ & $17.4 \pm 0.7$ & $23.4 \pm 0.4$ & $4.5 \pm 0.4$ & $0.3 \pm 0.1$ \\
\hline 3.35 to $4.75 \mathrm{~mm}$ & $23.2 \pm 0.3$ & $21.6 \pm 0.3$ & $20.2 \pm 0.5$ & $7.8 \pm 0.8$ & $0.2 \pm 0.1$ \\
\hline $\operatorname{pef}^{7}$ & $0.91 \pm 0.01$ & $0.90 \pm 0.01$ & $0.91 \pm 0.01$ & $0.71 \pm 0.01$ & $0.36 \pm 0.01$ \\
\hline peNDF ${ }^{8} \%$ of DM & $39.1 \pm 0.7$ & $36.6 \pm 0.3$ & $36.6 \pm 1.4$ & $40.0 \pm 1.8$ & - \\
\hline
\end{tabular}

${ }^{1} \mathrm{CONV}=$ diet containing TMF2R447 (Dow AgroSciences LLC, Indianapolis, IN), a conventional corn silage; BMR = diet containing F2F498 (Dow AgroSciences LLC), a bm3 corn silage; BMRFL = diet containing FBDAS3 (Dow AgroSciences LLC), a bm3 corn silage with floury kernel genetics.

${ }^{2}$ Number of samples $=3$.

${ }^{3}$ Measurements made with the Penn State Particle Separator (Lammers et al., 1996).

${ }^{4}$ pef $=$ physical effectiveness factor with the Penn State Particle Separator, \% of DM $\geq 4.0 \mathrm{~mm}$.

${ }^{5}$ peNDF $=$ physically effective NDF calculated from Penn State Particle Separator.

${ }^{6}$ Measurements made with the Ro-Tap shaker (W. S. Tyler Combustion Engineering Inc., Mentor, OH).

${ }^{7}$ pef $=$ physical effectiveness factor, $\%$ of $\mathrm{DM} \geq 1.18 \mathrm{~mm}$.

${ }^{8}$ peNDF $=$ physically effective $\mathrm{NDF}, \%$ of $\mathrm{DM} \geq 1.18 \mathrm{~mm}$. 
Neutral detergent fiber intake was greater for cows consuming both BMR $(9.2 \mathrm{~kg} / \mathrm{d} ; P=0.009)$ and BMRFL $(9.2 \mathrm{~kg} / \mathrm{d} P=0.003)$ compared with the CONV diet $(8.7 \mathrm{~kg} / \mathrm{d})$. In contrast, Taylor and Allen (2005b) observed no differences in NDF intake between cows fed diets containing conventional and bm 3 CS. Overall, response in DMI when cows are fed $b m 3$ and CONV has been variable (Barrière and Argillier, 1993). Because uNDFom intake was $0.7 \mathrm{~kg} / \mathrm{d}$ greater $(P=0.001)$ and potentially digestible NDF intake was $1.2 \mathrm{~kg} / \mathrm{d}$ less $(P=0.001)$ for cows consuming CONV compared with both BMR diets, the differences in NDF intake in our study may be due to interactions between gut fill, passage rate, and ruminal NDF digestibility. Starch intake was greater for BMRFL $(7.5 \mathrm{~kg} / \mathrm{d})$ compared with CONV $(7.0 \mathrm{~kg} / \mathrm{d} ; P=0.005)$, whereas the BMR diet was intermediate $(7.2 \mathrm{~kg} / \mathrm{d})$. This response in starch intake tracks with DMI and the dietary starch content, which was approximately 1 percentage unit greater for the BMRFL versus the other 2 diets.
Body weight and BCS were unaffected by dietary treatment. Change in BW $(\mathrm{kg} / 28-\mathrm{d}$ period) tended $(P$ $=0.08)$ to be greater for cows consuming the BMRFL diet $(20 \mathrm{~kg})$ compared with BMR $(5 \mathrm{~kg})$ and CONV $(8 \mathrm{~kg})$. Together with the greater ECM production for cows fed the BMR diets, this positive change in BW suggests that the BMRFL diet supplied more energy than either the BMR or CONV diets. To more thoroughly test this assertion, a longer-term study designed to measure changes in BW and BCS over time would be required.

\section{Lactational Performance}

Lactational performance of cows is presented in Table 7. Milk yield, FCM, SCM, and ECM were greater for cows consuming BMR and BMRFL diets compared with cows that were fed CONV $(P=0.001)$. Increased milk yields have been reported previously when cows were fed 30 to $40 \%$ bm3 CS-based diets in comparison

Table 4. Chemical composition and in vitro starch digestibility (mean $\pm \mathrm{SE}$ ) of the diets ${ }^{1}$

\begin{tabular}{|c|c|c|c|}
\hline \multirow[b]{2}{*}{ Item } & \multicolumn{3}{|c|}{$\operatorname{Diet}^{2}$} \\
\hline & $\mathrm{CONV}$ & BMR & BMRFL \\
\hline DM, \% & $45.4 \pm 0.4$ & $41.3 \pm 0.4$ & $44.2 \pm 0.2$ \\
\hline $\mathrm{CP}, \%$ of $\mathrm{DM}$ & $15.1 \pm 0.2$ & $14.8 \pm 0.1$ & $14.6 \pm 1.0$ \\
\hline Soluble protein, $\%$ of $\mathrm{CP}$ & $31.7 \pm 4.6$ & $33.0 \pm 3.7$ & $33.8 \pm 3.3$ \\
\hline NDICP, $3 \%$ of DM & $1.6 \pm 0.1$ & $1.8 \pm 0.2$ & $1.5 \pm 0.0$ \\
\hline $\mathrm{ADF}, \%$ of $\mathrm{DM}$ & $21.6 \pm 1.1$ & $20.9 \pm 0.4$ & $20.6 \pm 1.2$ \\
\hline $\mathrm{aNDF}^{4} \%$ of DM & $33.0 \pm 1.1$ & $32.6 \pm 0.4$ & $32.4 \pm 1.3$ \\
\hline $\mathrm{ADL}, \%$ of $\mathrm{DM}$ & $3.3 \pm 0.1$ & $2.7 \pm 0.1$ & $3.0 \pm 0.2$ \\
\hline Starch, $\%$ of DM & $26.1 \pm 0.9$ & $25.7 \pm 0.6$ & $27.1 \pm 1.3$ \\
\hline $\mathrm{ESC},{ }^{5} \%$ of DM & $4.4 \pm 0.6$ & $4.8 \pm 0.7$ & $5.1 \pm 0.8$ \\
\hline $\mathrm{NFC},{ }^{6} \%$ of DM & $41.8 \pm 1.1$ & $42.3 \pm 0.7$ & $43.4 \pm 1.1$ \\
\hline NSC, $\%$ of DM & $30.5 \pm 1.1$ & $30.5 \pm 1.0$ & $32.2 \pm 0.6$ \\
\hline Fat, $\%$ of DM & $4.6 \pm 0.0$ & $4.5 \pm 0.3$ & $4.3 \pm 0.2$ \\
\hline Ash, $\%$ of DM & $7.1 \pm 0.2$ & $7.6 \pm 0.7$ & $6.9 \pm 0.3$ \\
\hline $\mathrm{Ca}, \%$ of $\mathrm{DM}$ & $0.68 \pm 0.03$ & $0.68 \pm 0.02$ & $0.68 \pm 0.01$ \\
\hline $\mathrm{P}, \%$ of $\mathrm{DM}$ & $0.38 \pm 0.01$ & $0.37 \pm 0.01$ & $0.32 \pm 0.01$ \\
\hline $\mathrm{Mg}, \%$ of $\mathrm{DM}$ & $0.40 \pm 0.00$ & $0.40 \pm 0.00$ & $0.39 \pm 0.01$ \\
\hline $\mathrm{K}, \%$ of DM & $1.33 \pm 0.02$ & $1.31 \pm 0.03$ & $1.30 \pm 0.03$ \\
\hline $\mathrm{S}, \%$ of $\mathrm{DM}$ & $0.26 \pm 0.02$ & $0.26 \pm 0.02$ & $0.26 \pm 0.02$ \\
\hline $\mathrm{Na}, \%$ of $\mathrm{DM}$ & $0.49 \pm 0.00$ & $0.49 \pm 0.01$ & $0.49 \pm 0.01$ \\
\hline $\mathrm{Cl}, \%$ of $\mathrm{DM}$ & $0.55 \pm 0.04$ & $0.54 \pm 0.03$ & $0.56 \pm 0.04$ \\
\hline $\mathrm{Fe}, \mathrm{mg} / \mathrm{kg}$ of $\mathrm{DM}$ & $262.3 \pm 11.6$ & $277.7 \pm 20.12$ & $280.7 \pm 27.2$ \\
\hline $\mathrm{Cu}, \mathrm{mg} / \mathrm{kg}$ of $\mathrm{DM}$ & $17.3 \pm 0.9$ & $18.3 \pm 0.3$ & $17.7 \pm 0.7$ \\
\hline $\mathrm{Mn}, \mathrm{mg} / \mathrm{kg}$ of $\mathrm{DM}$ & $79.7 \pm 7.2$ & $81.7 \pm 5.7$ & $78.3 \pm 6.9$ \\
\hline $\mathrm{Zn}, \mathrm{mg} / \mathrm{kg}$ of $\mathrm{DM}$ & $85.7 \pm 8.2$ & $87.7 \pm 7.8$ & $82.0 \pm 6.0$ \\
\hline $\mathrm{NE}_{\mathrm{L}}, \mathrm{Mcal} / \mathrm{kg}$ & $1.71 \pm 0.03$ & $1.71 \pm 0.03$ & $1.70 \pm 0.03$ \\
\hline 7-h starch digestibility, $\%$ of starch & $77.3 \pm 3.1$ & $77.9 \pm 4.6$ & $77.8 \pm 3.3$ \\
\hline
\end{tabular}

${ }^{1}$ Number of samples $=3$.

${ }^{2} \mathrm{CONV}=$ diet containing TMF2R447 (Dow AgroSciences LLC, Indianapolis, IN), a conventional corn silage; $\mathrm{BMR}=$ diet containing F2F498 (Dow AgroSciences LLC), a bm3 corn silage; BMRFL = diet containing FBDAS3 (Dow AgroSciences LLC), a bm3 corn silage with floury kernel genetics.

${ }^{3} \mathrm{NDICP}=$ neutral detergent insoluble CP.

${ }^{4} \mathrm{NDF}$ with residual ash using $\alpha$-amylase without sodium sulfite.

${ }^{5} \mathrm{ESC}=$ ethanol-soluble carbohydrate

${ }^{6} \mathrm{NFC}=100-[\mathrm{CP} \%+(\mathrm{NDF} \%-\mathrm{NDICP} \%)+$ fat $\%+$ ash $\%] ; \mathrm{NRC}(2001)$. 
Table 5. Particle size distribution (mean $\pm \mathrm{SE}$ ) of the $\operatorname{diets}^{1}$

\begin{tabular}{|c|c|c|c|}
\hline \multirow[b]{2}{*}{ Item } & \multicolumn{3}{|c|}{ Diet $^{2}$} \\
\hline & $\mathrm{CONV}$ & BMR & BMRFL \\
\hline \multicolumn{4}{|c|}{ Particle size distribution, ${ }^{3} \%$ as-fed } \\
\hline$>19.0 \mathrm{~mm}$ & $3.7 \pm 0.5$ & $2.5 \pm 0.3$ & $4.0 \pm 0.3$ \\
\hline 8.0 to $19.0 \mathrm{~mm}$ & $53.1 \pm 0.5$ & $55.3 \pm 0.5$ & $55.5 \pm 0.6$ \\
\hline 4.0 to $8.0 \mathrm{~mm}$ & $10.4 \pm 0.2$ & $11.0 \pm 0.2$ & $10.2 \pm 0.2$ \\
\hline$<4.0 \mathrm{~mm}$ & $32.7 \pm 0.2$ & $31.2 \pm 0.3$ & $30.3 \pm 0.4$ \\
\hline \multicolumn{4}{|c|}{ Particle size distribution, ${ }^{4} \%$ of DM } \\
\hline$>19.00 \mathrm{~mm}$ & $0.1 \pm 0.0$ & $0.1 \pm 0.1$ & $0.1 \pm 0.0$ \\
\hline 13.20 to $19.00 \mathrm{~mm}$ & $0.2 \pm 0.1$ & $0.0 \pm 0.0$ & $0.2 \pm 0.1$ \\
\hline 9.50 to $13.20 \mathrm{~mm}$ & $2.3 \pm 0.5$ & $2.8 \pm 0.7$ & $3.1 \pm 0.6$ \\
\hline 6.70 to $9.50 \mathrm{~mm}$ & $10.1 \pm 0.6$ & $9.7 \pm 1.5$ & $14.2 \pm 1.1$ \\
\hline 4.75 to $6.70 \mathrm{~mm}$ & $10.2 \pm 0.3$ & $9.3 \pm 0.1$ & $12.2 \pm 0.2$ \\
\hline 3.35 to $4.75 \mathrm{~mm}$ & $12.7 \pm 0.4$ & $12.7 \pm 0.2$ & $11.9 \pm 0.3$ \\
\hline 2.36 to $3.35 \mathrm{~mm}$ & $10.6 \pm 0.2$ & $11.1 \pm 0.3$ & $9.4 \pm 0.2$ \\
\hline 1.18 to $2.36 \mathrm{~mm}$ & $19.4 \pm 0.1$ & $20.8 \pm 0.6$ & $17.8 \pm 0.3$ \\
\hline 0.60 to $1.18 \mathrm{~mm}$ & $17.6 \pm 0.3$ & $18.9 \pm 0.4$ & $16.6 \pm 0.7$ \\
\hline 0.30 to $0.60 \mathrm{~mm}$ & $11.6 \pm 0.4$ & $10.4 \pm 0.4$ & $10.2 \pm 0.2$ \\
\hline$<0.30 \mathrm{~mm}$ & $5.3 \pm 0.4$ & $4.2 \pm 0.2$ & $4.4 \pm 0.1$ \\
\hline pef $^{5}$ & $0.69 \pm 0.0$ & $0.69 \pm 0.0$ & $0.70 \pm 0.0$ \\
\hline peNDF ${ }^{6} \%$ of DM & $21.5 \pm 1.0$ & $21.7 \pm 0.5$ & $22.3 \pm 1.02$ \\
\hline
\end{tabular}

${ }^{1}$ Number of samples $=3$.

${ }^{2} \mathrm{CONV}=$ diet containing TMF2R447 (Dow AgroSciences LLC, Indianapolis, IN), a conventional corn silage; $\mathrm{BMR}=$ diet containing F2F498 (Dow AgroSciences LLC), a bm3 corn silage; BMRFL = diet containing FBDAS3 (Dow AgroSciences LLC), a bm3 corn silage with floury kernel genetics.

${ }^{3}$ Measurements made with the Penn State Particle Separator.

${ }^{4}$ Measurements made with the Ro-Tap shaker (W. S. Tyler Combustion Engineering Inc., Mentor, OH).

${ }^{5}$ pef $=$ physical effectiveness factor, $\%$ of $\mathrm{DM} \geq 1.18 \mathrm{~mm}$.

${ }^{6}$ peNDF $=$ physically effective neutral detergent fiber, $\%$ of $\mathrm{DM} \geq 1.18 \mathrm{~mm}$.

to diets containing conventional CS (Ferraretto and Shaver, 2015; Lim et al., 2015). Milk fat content was greater for cows consuming CONV (4.0\%) compared with BMR $(3.85 \% ; P=0.02)$ and BMRFL diets $(3.87 \%$; $P=0.04)$. However, milk fat yield was greatest for cows fed BMRFL $(1.87 \mathrm{~kg} / \mathrm{d})$ compared with CONV $(1.74 \mathrm{~kg} / \mathrm{d} ; P=0.001)$ and BMR diets $(1.80 \mathrm{~kg} / \mathrm{d} ; P$ $=0.05)$. Lower milk fat content for cows fed bm3 CS hybrids may be due to an increased supply of PUFA associated with greater DMI (Ferraretto and Shaver,

Table 6. Least squares means of DMI, BW, and BCS of multiparous Holstein cows fed diets containing different sources of corn silage

\begin{tabular}{|c|c|c|c|c|c|}
\hline \multirow[b]{2}{*}{ Item } & \multicolumn{3}{|c|}{ Diet $^{1}$} & \multirow[b]{2}{*}{ SEM } & \multirow[b]{2}{*}{$P$-value } \\
\hline & CONV & BMR & BMRFL & & \\
\hline DMI, kg/d & $26.8^{\mathrm{b}}$ & $28.0^{\mathrm{a}}$ & $27.6^{\mathrm{ab}}$ & 0.5 & 0.016 \\
\hline DMI, $\%$ of BW & $3.87^{\mathrm{b}}$ & $4.03^{\mathrm{a}}$ & $3.94^{\mathrm{ab}}$ & 0.08 & 0.006 \\
\hline OM intake, $\mathrm{kg} / \mathrm{d}$ & $24.9^{\mathrm{b}}$ & $25.8^{\mathrm{a}}$ & $25.7^{\mathrm{ab}}$ & 0.47 & 0.029 \\
\hline NDF intake, $\mathrm{kg} / \mathrm{d}$ & $8.7^{\mathrm{b}}$ & $9.2^{\mathrm{a}}$ & $9.2^{\mathrm{a}}$ & 0.16 & 0.002 \\
\hline uNDFom intake, ${ }^{2} \mathrm{~kg} / \mathrm{d}$ & $2.3^{\mathrm{a}}$ & $1.6^{\mathrm{b}}$ & $1.6^{\mathrm{b}}$ & 0.03 & 0.001 \\
\hline pdNDF intake, ${ }^{3} \mathrm{~kg} / \mathrm{d}$ & $6.4^{\mathrm{b}}$ & $7.6^{\mathrm{a}}$ & $7.6^{\mathrm{a}}$ & 0.14 & 0.001 \\
\hline Starch intake, $\mathrm{kg} / \mathrm{d}$ & $7.0^{\mathrm{b}}$ & $7.2^{\mathrm{ab}}$ & $7.5^{\mathrm{a}}$ & 0.17 & 0.007 \\
\hline $\mathrm{BW}, \mathrm{kg}$ & 696 & 698 & 705 & 16 & 0.21 \\
\hline BW change, $\mathrm{kg} / 28-\mathrm{d}$ period & 8 & 5 & 20 & 4 & 0.08 \\
\hline BCS & 2.86 & 2.78 & 2.84 & 0.08 & 0.18 \\
\hline BCS change, $\mathrm{kg} / 28$-d period & -0.04 & 0.05 & -0.01 & 0.04 & 0.41 \\
\hline
\end{tabular}

$\overline{\mathrm{a}, \mathrm{b}}$ Least squares means within a row without a common superscript differ $(P \leq 0.05)$.

${ }^{1} \mathrm{CONV}=$ diet containing TMF2R447 (Dow AgroSciences LLC, Indianapolis, IN), a conventional corn silage; BMR = diet containing F2F498 (Dow AgroSciences LLC), a bm3 corn silage; BMRFL = diet containing FBDAS3 (Dow AgroSciences LLC), a $b m 3$ corn silage with floury kernel genetics.

${ }^{2}$ Undigested NDF, determined after a $240-\mathrm{h}$ ruminal in vitro incubation.

${ }^{3}$ Potentially digestible NDF $=(\mathrm{NDF}-\mathrm{uNDFom})$. 
2015) and increased passage rate characteristic of cows fed the BMR diet. However, the increase in milk fat yield from cows consuming BMRFL over BMR suggests that increases in ruminal starch fermentation did not overwhelm buffering capacity or microbial populations, and that there was sufficient physically effective fiber in the diet.

Milk true protein content and yield were greater for cows fed BMR and BMRFL diets compared with cows fed CONV $(P<0.03$ and $P=0.001$, respectively $)$. Lim et al. (2015) also reported greater protein content and yield for cows fed bm3 CS diets compared with conventional CS diets. Differences in protein content and yield may be related to greater microbial protein synthesis due to increased ruminal OM digestibility for cows fed bm3 CS diets. When Ramirez et al. (2012) estimated microbial CP by measuring purine derivatives in diets containing $40 \%$ bm 3 or dual-purpose CS, bm3 CS diets resulted in greater microbial $\mathrm{CP}$ flows. These results agree well with our study where the Fermentrics data showed greater microbial biomass production for the BMR and particularly for the BMRFL hybrids (Table 2).
Solids nonfat content and yield were greater for cows fed BMR and BMRFL diets compared with cows fed CONV $(P=0.001$; Table 7$)$. Milk urea-N concentration was greater for cows consuming CONV $(13.60 \mathrm{mg} / \mathrm{dL})$ compared with BMR $(11.61 \mathrm{mg} / \mathrm{dL} ; P=0.001)$ and BMRFL $(11.16 \mathrm{mg} / \mathrm{dL} ; P=0.001)$. Others have also reported a reduction in MUN concentration when feeding BMR CS associated with greater ruminal carbohydrate digestibility and efficiency of microbial protein synthesis (Taylor and Allen, 2005b; Holt et al., 2013b).

Feed efficiency (milk/DMI) was greatest for cows consuming BMRFL (1.74 kg of milk/ $\mathrm{kg}$ of DMI) compared with cows consuming CONV (1.63 kg of milk/ $\mathrm{kg}$ of DMI; $P=0.001$ ) and intermediate for cows consuming the BMR diet $(1.69 \mathrm{~kg}$ of milk/ $\mathrm{kg}$ of DMI). Cows consuming BMRFL had greater efficiency of production of $3.5 \%$ FCM, SCM, and ECM when compared with either the BMR- or CONV-fed cows $(P<0.005$; Table 7). Several studies have reported that feed efficiency is similar for cows fed bm3 and conventional CS diets (Stone et al., 2012; Holt et al., 2013a; Ferraretto and Shaver, 2015). However, Taylor and Allen (2005a) reported that floury versus vitreous dry grain

Table 7. Least squares means of lactational performance and feed efficiency for multiparous Holstein cows fed diets containing different sources of corn silage

\begin{tabular}{|c|c|c|c|c|c|}
\hline \multirow[b]{2}{*}{ Item } & \multicolumn{3}{|c|}{$\operatorname{Diet}^{1}$} & \multirow[b]{2}{*}{ SEM } & \multirow[b]{2}{*}{$P$-value } \\
\hline & CONV & BMR & BMRFL & & \\
\hline \multicolumn{6}{|l|}{ Milk yield } \\
\hline Milk, kg/d & $43.8^{\mathrm{b}}$ & $47.3^{\mathrm{a}}$ & $48.0^{\mathrm{a}}$ & 1.3 & 0.001 \\
\hline Sample day milk, $\mathrm{kg} / \mathrm{d}$ & $43.3^{\mathrm{b}}$ & $47.0^{\mathrm{a}}$ & $48.3^{\mathrm{a}}$ & 1.4 & 0.001 \\
\hline $3.5 \% \mathrm{FCM}, \mathrm{kg} / \mathrm{d}$ & $47.1^{\mathrm{b}}$ & $49.7^{\mathrm{a}}$ & $51.2^{\mathrm{a}}$ & 1.4 & 0.001 \\
\hline $\mathrm{SCM}{ }^{2} \mathrm{~kg} / \mathrm{d}$ & $43.1^{\mathrm{b}}$ & $46.2^{\mathrm{a}}$ & $47.8^{\mathrm{a}}$ & 1.4 & 0.001 \\
\hline $\mathrm{ECM}, \mathrm{kg} / \mathrm{d}$ & $47.2^{\mathrm{b}}$ & $50.3^{\mathrm{a}}$ & $51.8^{\mathrm{a}}$ & 1.5 & 0.001 \\
\hline \multicolumn{6}{|l|}{ Milk composition } \\
\hline Fat, $\%$ & $4.00^{\mathrm{a}}$ & $3.85^{\mathrm{b}}$ & $3.87^{\mathrm{b}}$ & 0.07 & 0.010 \\
\hline Fat, $\mathrm{kg} / \mathrm{d}$ & $1.74^{\mathrm{b}}$ & $1.80^{\mathrm{b}}$ & $1.87^{\mathrm{a}}$ & 0.06 & 0.001 \\
\hline True protein, $\%$ & $3.13^{\mathrm{b}}$ & $3.19^{\mathrm{a}}$ & $3.19^{\mathrm{a}}$ & 0.07 & 0.010 \\
\hline True protein, $\mathrm{kg} / \mathrm{d}$ & $1.36^{\mathrm{b}}$ & $1.49^{\mathrm{a}}$ & $1.54^{\mathrm{a}}$ & 0.06 & 0.001 \\
\hline Lactose, $\%$ & $4.80^{\mathrm{b}}$ & $4.85^{\mathrm{a}}$ & $4.84^{\mathrm{ab}}$ & 0.03 & 0.012 \\
\hline Lactose, $\mathrm{kg} / \mathrm{d}$ & $2.08^{\mathrm{b}}$ & $2.28^{\mathrm{a}}$ & $2.34^{\mathrm{a}}$ & 0.07 & 0.001 \\
\hline SNF, \% & $8.80^{\mathrm{b}}$ & $8.93^{\mathrm{a}}$ & $8.93^{\mathrm{a}}$ & 0.06 & 0.001 \\
\hline $\mathrm{SNF}, \mathrm{kg} / \mathrm{d}$ & $3.82^{\mathrm{b}}$ & $4.19^{\mathrm{a}}$ & $4.32^{\mathrm{a}}$ & 0.13 & 0.001 \\
\hline MUN, mg/dL & $13.60^{\mathrm{a}}$ & $11.61^{\mathrm{b}}$ & $11.16^{\mathrm{b}}$ & 0.30 & 0.001 \\
\hline SCS & 1.93 & 1.58 & 1.17 & 0.40 & 0.350 \\
\hline \multicolumn{6}{|l|}{ Feed efficiency } \\
\hline Milk/DMI & $1.63^{\mathrm{b}}$ & $1.69^{\mathrm{ab}}$ & $1.74^{\mathrm{a}}$ & 0.04 & 0.001 \\
\hline $3.5 \% \mathrm{FCM} / \mathrm{DMI}$ & $1.75^{\mathrm{b}}$ & $1.77^{\mathrm{b}}$ & $1.85^{\mathrm{a}}$ & 0.04 & 0.004 \\
\hline $\mathrm{SCM} / \mathrm{DMI}$ & $1.60^{\mathrm{b}}$ & $1.65^{\mathrm{b}}$ & $1.73^{\mathrm{a}}$ & 0.04 & 0.001 \\
\hline $\mathrm{ECM} / \mathrm{DMI}$ & $1.76^{\mathrm{b}}$ & $1.79^{\mathrm{b}}$ & $1.87^{\mathrm{a}}$ & 0.04 & 0.001 \\
\hline Milk N efficiency, \% & $35.3^{\mathrm{c}}$ & $38.1^{\mathrm{b}}$ & $40.4^{\mathrm{a}}$ & 1.2 & 0.001 \\
\hline
\end{tabular}

${ }^{a-c}$ Least squares means within a row without a common superscript differ $(P \leq 0.05)$.

${ }^{1} \mathrm{CONV}=$ diet containing TMF2R447 (Dow AgroSciences LLC, Indianapolis, IN), a conventional corn silage; $\mathrm{BMR}=$ diet containing F2F498 (Dow AgroSciences LLC), a bm3 corn silage; BMRFL = diet containing FBDAS3 (Dow AgroSciences LLC), a bm3 corn silage with floury kernel genetics.

${ }^{2} \mathrm{SCM}=$ solids-corrected milk. 
Table 8. Least squares means of eating and ruminating behavior for multiparous Holstein cows fed diets containing different sources of corn silage

\begin{tabular}{|c|c|c|c|c|c|}
\hline \multirow[b]{2}{*}{ Item } & \multicolumn{3}{|c|}{ Diet $^{1}$} & \multirow[b]{2}{*}{ SEM } & \multirow[b]{2}{*}{$P$-value } \\
\hline & $\mathrm{CONV}$ & BMR & BMRFL & & \\
\hline \multicolumn{6}{|l|}{ Chewing } \\
\hline $\min / \mathrm{d}$ & 838 & 826 & 832 & 16 & 0.645 \\
\hline $\min / \mathrm{kg}$ of $\mathrm{DM}$ & $31.4^{\mathrm{a}}$ & $29.7^{\mathrm{b}}$ & $30.3^{\mathrm{ab}}$ & 0.8 & 0.006 \\
\hline $\min / \mathrm{kg}$ of $\mathrm{NDF}$ & $96.5^{\mathrm{a}}$ & $90.8^{\mathrm{b}}$ & $90.6^{\mathrm{b}}$ & 2.3 & 0.001 \\
\hline $\mathrm{min} / \mathrm{kg}$ of $\mathrm{peNDF}^{2}$ & $143.1^{\mathrm{a}}$ & $138.3^{\mathrm{b}}$ & $141.2^{\mathrm{ab}}$ & 3.6 & 0.047 \\
\hline \multicolumn{6}{|l|}{ Eating } \\
\hline $\min / \mathrm{d}$ & 294 & 294 & 284 & 11 & 0.410 \\
\hline $\mathrm{min} / \mathrm{kg}$ of $\mathrm{DM}$ & 11.0 & 10.5 & 10.4 & 0.4 & 0.126 \\
\hline $\mathrm{min} / \mathrm{kg}$ of $\mathrm{NDF}$ & $33.9^{\mathrm{a}}$ & $32.3^{\mathrm{ab}}$ & $30.9^{\mathrm{b}}$ & 1.3 & 0.027 \\
\hline $\mathrm{min} / \mathrm{kg}$ of peNDF & 50.2 & 49.2 & 48.3 & 1.9 & 0.370 \\
\hline \multicolumn{6}{|l|}{ Ruminating } \\
\hline $\min / \mathrm{d}$ & 543 & 532 & 547 & 13 & 0.303 \\
\hline $\min / \mathrm{kg}$ of $\mathrm{DM}$ & $20.4^{\mathrm{a}}$ & $19.1^{\mathrm{b}}$ & $19.9^{\mathrm{ab}}$ & 0.6 & 0.006 \\
\hline $\mathrm{min} / \mathrm{kg}$ of $\mathrm{NDF}$ & $62.6^{\mathrm{a}}$ & $58.5^{\mathrm{b}}$ & $59.6^{\mathrm{b}}$ & 1.9 & 0.002 \\
\hline $\mathrm{min} / \mathrm{kg}$ of peNDF & $92.9^{\mathrm{a}}$ & $89.1^{\mathrm{b}}$ & $93.0^{\mathrm{a}}$ & 3.0 & 0.023 \\
\hline
\end{tabular}

${ }^{\mathrm{a}, \mathrm{b}}$ Least squares means within a row without a common superscript differ $(P \leq 0.05)$.

${ }^{1} \mathrm{CONV}=$ diet containing TMF2R447 (Dow AgroSciences LLC, Indianapolis, IN), a conventional corn silage; $\mathrm{BMR}=$ diet containing F2F498 (Dow AgroSciences LLC), a bm3 corn silage; BMRFL = diet containing FBDAS3 (Dow AgroSciences LLC), a $b m 3$ corn silage with floury kernel genetics.

${ }^{2}$ peNDF $=$ physically effective neutral detergent fiber.

tended to increase $3.5 \% \mathrm{FCM}$, indicating that a source of more digestible floury grain in diets can improve feed efficiency. In addition, Longuski et al. (2002) observed that CS with floury versus vitreous endosperm tended to increase efficiency of FCM production.

Milk N efficiency was greatest for cows consuming BMRFL (40.4\%), compared with cows consuming BMR $(38.1 \% ; P=0.03)$ and CONV diets $(35.3 \% ; P=0.001)$. Milk $\mathrm{N}$ efficiency was also greater for cows consuming BMR compared with CONV $(P=0.006)$. Holt et al. (2013b) demonstrated that feeding forages greater in ruminal degradability such as bm3 CS resulted in improved $\mathrm{N}$ utilization. Our study indicates that the combined effects of greater ruminal fiber degradability and greater total carbohydrate fermentability provided by feeding the BMRFL diet enhanced $\mathrm{N}$ utilization in dairy cows.

\section{Chewing Behavior}

Chewing, eating, and ruminating behavior expressed as minutes per day were similar across all diets (Table 8). Interestingly, even though DMI was the least, chewing and ruminating time expressed as minutes per $\mathrm{kg}$ of DM was greater for cows fed the CONV diet compared with the BMR diet $(P=0.006)$ but did not differ when compared with cows fed the BMRFL diet. Chewing time per kilogram of NDF was greater for cows consuming CONV (96.5 min $/ \mathrm{kg}$ of NDF) compared with BMR and BMRFL (91 min $/ \mathrm{kg}$ of NDF; $P=0.002$ ). Forage fragility, or how easily the particle breaks down when chewed, while not incorporated into pef values, plays a role in chewing response to forage NDF (Mertens, 1997). Differences in forage fragility for BMR and BMRFL versus CONV may help account for decreased chewing time per kilogram of NDF, which subsequently allowed for $0.5 \mathrm{~kg} / \mathrm{d}$ greater NDF intake for cows consuming bm3 CS hybrids. Fiber with lower lignin or uNDFom content requires less fracture force for exposure of cell wall to microbial degradation (Zi et al., 2017). Eating time on a NDF basis was greater for cows consuming CONV (33.9 min $/ \mathrm{kg}$ of NDF) compared with cows consuming BMRFL (30.9 min $/ \mathrm{kg}$ NDF; $P=0.03)$ and intermediate for cows consuming BMR $(32.3 \mathrm{~min} / \mathrm{kg}$ of $\mathrm{NDF}$ ). Cows consuming the CONV diet ruminated longer per kilogram of NDF than either group of cows fed bm3 $(P=0.002)$. Grant and Ferraretto (2018) reported that eating time was lower when cows are fed silages with greater NDF digestibility, which is associated with greater fragility and less chewing per kilogram of NDF consumed.

Chewing time on a kilogram of peNDF basis was greater when cows consumed CONV (143.1 min $/ \mathrm{kg}$ of peNDF) compared with cows consuming BMR (138.3 $\mathrm{min} / \mathrm{kg}$ of peNDF, $P=0.04$ ), but did not differ from cows consuming the BMRFL diet $(141.2 \mathrm{~min} / \mathrm{kg}$ of peNDF). Cows ruminated 4 min less per $\mathrm{kg}$ of peNDF consumed when fed the BMR diet compared with CONV and BMRFL $(P=0.05, P=0.04$, respectively). Yang and Beauchemin (2009) reported that chewing activity was positively correlated with greater peNDF content $(\mathrm{r}=0.57)$ and mean ruminal $\mathrm{pH}(\mathrm{r}=0.75)$. 
Table 9. Least squares means of apparent total-tract nutrient digestibility (\%) of the diets for multiparous Holstein cows fed diets containing different sources of corn silage

\begin{tabular}{|c|c|c|c|c|c|}
\hline \multirow[b]{2}{*}{ Item } & \multicolumn{3}{|c|}{$\operatorname{Diet}^{1}$} & \multirow[b]{2}{*}{ SEM } & \multirow[b]{2}{*}{$P$-value } \\
\hline & CONV & BMR & BMRFL & & \\
\hline $\mathrm{OM}$ & 74.2 & 74.6 & 74.3 & 0.3 & 0.31 \\
\hline NDF & 58.2 & 58.4 & 57.8 & 0.5 & 0.62 \\
\hline Potentially digestible NDF & 73.0 & 73.0 & 72.9 & 0.5 & 0.98 \\
\hline Starch & 99.3 & 99.4 & 99.3 & 0.1 & 0.42 \\
\hline
\end{tabular}

${ }^{1} \mathrm{CONV}=$ diet containing TMF2R447 (Dow AgroSciences LLC, Indianapolis, IN), a conventional corn silage; BMR = diet containing F2F498 (Dow AgroSciences LLC), a bm3 corn silage; BMRFL = diet containing FBDAS3 (Dow AgroSciences LLC), a bm3 corn silage with floury kernel genetics.

In our study, chewing and rumination response may have been influenced more by differences in fragility between CONV and BMR CS hybrids than particle size distribution since all diets had similar peNDF content (Mertens, 1997; Grant and Ferraretto, 2018).

\section{Total-Tract Digestibility}

Apparent total-tract digestibility for all nutrients was unaffected by dietary treatment (Table 9). Total-tract digestibility of $\mathrm{OM}, \mathrm{NDF}$, and potentially digestible NDF averaged $74.4,58.1$, and $73.0 \%$, respectively. Ferraretto and Shaver (2015) reported that treatments containing bm $3 \mathrm{CS}$ had greater total-tract NDF digestibility $(44.8 \%)$ compared with conventional CS (42.3\%). In contrast, similar NDF digestibility between bm3 3 and conventional CS was observed by Ferraretto et al. (2015a) and thought to be related to increased passage rate of digesta associated with greater DMI for cows fed bm3 CS (Moharrery et al., 2014).

Total-tract starch digestibility was similar among treatments, averaging 99.3\%. Despite apparent differences in ivSD between BMRFL and the other 2 CS hybrids, total-tract starch digestion was similar. A meta-analysis of published trials (Ferraretto and Shaver, 2015) found a 6-percentage-unit decrease in ruminal starch digestibility but only a 1.4-percentage-unit decrease in total-tract starch digestibility for cows fed bm3 CS compared with conventional CS. One important factor in interpreting the digestibility results is the relatively high moisture content of all the silages (31.7, 28.7 , and $30.9 \%$ of DM for CONV, BMR, and BMRFL, respectively). Previous research has found that CS with greater moisture content would have greater totaltract starch digestibility associated with a decreased proportion of vitreous endosperm in the kernel because it is less mature (Ferraretto and Shaver, 2012). The moisture content of the CS assessed in this study may have influenced the observed total-tract starch digestibility responses and the changes in starch digestibility observed in the mini-silos over time of fermentation.
Future research should compare these CS genetics at lower silage moisture content.

\section{CONCLUSIONS}

The results of this experiment show that a novel bm3 CS hybrid with FL2 genetics containing softer endosperm was associated with improved NDF intake similar to the traditional bm3 hybrid, while also increasing starch intake compared with conventional CS. Greater feed efficiency (FCM, SCM, and ECM) indicated that a bm3 CS hybrid containing softer endosperm improves energy utilization compared with $b m 3$ and conventional CS. Additionally, improved milk $\mathrm{N}$ efficiency indicated that greater ruminal degradability and greater carbohydrate fermentability can be achieved when feeding a BMRFL diet. Availability of a bm3 CS hybrid with softer endosperm will allow dairy producers to feed a high-quality corn silage that will efficiently satisfy both fiber and energy requirements of high-producing dairy cows.

\section{ACKNOWLEDGMENTS}

We want to thank Dow AgroSciences LLC for funding this experiment and the farm and research staff at the William H. Miner Agricultural Research Institute for care of the cows.

\section{REFERENCES}

Allen, M. S. 2000. Effects of diet on short-term regulation of feed intake by lactating dairy cattle. J. Dairy Sci. 83:1598-1624.

AOAC International. 2012. Official Methods of Analysis. 19th ed. AOAC International, Arlington, VA.

Barrière, Y., and O. Argillier. 1993. Brown-midrib genes of maize: A review. Agronomie 13:865-876.

Blummel, M., H. Steingab, and K. Becker. 1997. The relationship between in vitro gas production, in vitro microbial biomass yield, ad $\mathrm{N}$ incorporation and its implications for the prediction of voluntary feed intake of roughages. Br. J. Nutr. 77:911-921.

Dairyland Laboratories Inc. 2013. Fermentrics Interpretation and Guidelines. Accessed Jan. 23, 2019. http://www.fermentrics.com/ images/Fermentrics\%20Interpretation_September\%202013.pdf. 
Dombrink-Kurtzman, M. A., and J. A. Beitz. 1993. Zein composition in hard and soft endosperm of maize. Cereal Chem. 70:105-108.

Dubois, M., K. A. Gilles, J. K. Hamilton, P. A. Rebers, and F. Smith. 1956. Calorimetric method for determination of sugars and related substances. Anal. Chem. 28:350-356.

Ebling, T. L., and L. Kung Jr. 2004. A comparison of processed conventional corn silage to unprocessed and processed brown midrib corn silage on intake, digestion, and milk production by dairy cows. J. Dairy Sci. 87:2519-2526.

Ferguson, J. D., D. T. Galligan, and N. Thomsen. 1994. Principal descriptors of body condition score in Holstein cows. J. Dairy Sci. $77: 2695-2703$.

Ferraretto, L. F., P. M. Crump, and R. D. Shaver. 2015b. Effect of ensiling time and exogenous protease addition to whole-plant corn silage of various hybrids, maturities and chop lengths on nitrogen fractions and ruminal in vitro starch digestibility. J. Dairy Sci. 98:8869-8881.

Ferraretto, L. F., A. C. Fonseca, C. J. Sniffen, A. Formigoni, and R. D. Shaver. 2015a. Effect of corn silage hybrids differing in starch and neutral detergent fiber digestibility on lactation performance and total-tract nutrient digestibility by dairy cows. J. Dairy Sci. 98:395-405.

Ferraretto, L. F., and R. D. Shaver. 2012. Meta-analysis: Effect of corn silage harvest practices on intake, digestion, and milk production by dairy cows. Prof. Anim. Sci. 28:141-149.

Ferraretto, L. F., and R. D. Shaver. 2015. Effects of whole-plant corn silage hybrid type on intake, digestion, ruminal fermentation, and lactation performance by dairy cows through a meta-analysis. J. Dairy Sci. 98:2662-2675.

Ferraretto, L. F., R. D. Shaver, S. Massie, R. Singo, D. M. Taysom, and J. P. Brouillette. 2015c. Effect of ensiling time and hybrid type on fermentation profile, nitrogen fractions and ruminal in vitro starch and NDF digestibility in whole-plant corn silages. Prof. Anim. Sci. 31:146-152.

Giuberti, G., A. Gallo, F. Masoero, L. F. Ferraretto, P. C. Hoffman, and R. D. Shaver. 2014. Factors affecting starch utilization in large animal food production system: A review. Starke 66:72-90.

Goering, H. K., and P. J. Van Soest. 1970. Forage Fiber Analysis: Apparatus, Reagents, Procedures, and Some Applications. Agric. Handbook No. 379. Agricultural Research Service, USDA, Washington. DC.

Grant, R. J., and L. F. Ferraretto. 2018. Silage review: Silage feeding management: Silage characteristics and dairy cow feeding behavior. J. Dairy Sci. 101:4111-4121.

Hall, M. B. 2009. Determination of starch, including maltooligosaccharides, in animal feeds: Comparison of methods and a method recommended for AOAC collaborative study. J. AOAC Int. 92:42-49.

Hoffman, P. C., N. M. Esser, R. D. Shaver, W. K. Coblentz, M. P. Scott, A. L. Bodnar, R. J. Schmidt, and R. C. Charley. 2011. Influence of ensiling time and inoculation on alteration of the starchprotein matrix in high-moisture corn. J. Dairy Sci. 94:2465-2474.

Holt, M. S., J.-S. Eun, C. R. Thacker, A. J. Young, X. Dai, and K. E. Nestor Jr. 2013a. Effects of feeding brown midrib corn silage with a high dietary concentration of alfalfa hay on lactational performance of Holstein dairy cows for the first 180 days of lactation. J. Dairy Sci. 96:515-523.

Holt, M. S., K. Neal, J.-S. Eun, A. J. Young, J. O. Hall, and K. E. Nestor Jr. 2013b. Corn silage hybrid type and quality of alfalfa hay affect dietary nitrogen utilization by early lactating dairy cows. J. Dairy Sci. 96:6564-6576.

Krishnamoorthy, U., T. V. Muscato, C. J. Sniffen, and P. J. Van Soest. 1982. Nitrogen fractions in selected feedstuffs. J. Dairy Sci. $65: 217-225$.

Lammers, B. P., D. R. Buckmaster, and A. J. Heinrichs. 1996. A simple method for the analysis of particle sizes of forage and total mixed ration. J. Dairy Sci. 79:922-928.

Larson, J., and P. C. Hoffman. 2008. Technical note: A method to quantify prolamin proteins in corn that are negatively related to starch digestibility in ruminants. J. Dairy Sci. 91:4834-4839.
Lim, J. M., K. E. Nestor Jr., and L. Kung Jr. 2015. The effect of hybrid type and dietary proportions of corn silage on the lactation performance of high-producing dairy cows. J. Dairy Sci. 98:1195-1203.

Longuski, R. A., K. C. Fanning, M. S. Allen, R. J. Grant, and J. F. Beck. 2002. Endosperm type and kernel processing of corn silage: Effects on short-term lactational performance in dairy cows. J. Dairy Sci. 85(Suppl. 1):204. (Abstr.)

Lopes, J. C., R. D. Shaver, P. C. Hoffman, M. S. Akins, S. J. Bertics, H. Gencoglu, and J. G. Coors. 2009. Type of corn endosperm influences nutrient digestibility in lactating dairy cows. J. Dairy Sci. 92:4541-4548.

Maynard, L. A., J. K. Loosli, H. F. Hintz, and R. G. Warner. 1979 Digestive processes in different species. Pages 21-46 in Animal Nutrition. McGraw-Hill Inc., New York, NY.

Mertens, D. R. 1997. Creating a system for meeting the fiber requirements of dairy cows. J. Dairy Sci. 80:1463-1481.

Mertens, D. R. 2002. Determination of starch in large particles. RoTap shaker method. Revised Apr. 2002. US Dairy Forage Research Center, Madison, WI.

Moharrery, A., M. Larsen, and M. R. Weisbjerg. 2014. Starch digestion in the rumen, small intestine, and hind gut of dairy cows - A meta-analysis. Anim. Feed Sci. Technol. 192:1-14.

National Research Council. 2001. Nutrient Requirements of Dairy Cattle. 7th rev. ed. National Academy Press, Washington, DC.

Raffrenato, E., C. F. Nicholson, and M. E. Van Amburgh. 2019. Development of a mathematical model to predict pool sizes and rates of digestion of 2 pools of digestible neutral detergent fiber and an undigested neutral detergent fiber fraction within various forages. J. Dairy Sci. 102:351-364.

Ramirez, H. A. R., K. Nestor, L. O. Tedeschi, T. R. Callaway, S. E. Dowd, S. C. Fernando, and P. J. Kononoff. 2012. The effect of brown midrib corn silage and dried distiller's grains with solubles on milk production, nitrogen utilization and microbial community structure in dairy cows. Can. J. Anim. Sci. 92:365-380.

Richards, C. J., F. F. Peterson, R. A. Britton, R. A. Stock, and C. R. Krehbiel. 1995. In vitro starch disappearance procedure modifications. Anim. Feed Sci. Technol. 55:35-45.

Schofield, P., and A. N. Pell. 1995. Validity of using accumulated gas pressure readings to measure forage digestion in vitro: A comparison involving three forages. J. Dairy Sci. 78:2230-2238.

Shook, G. E. 1993. Genetic improvement of mastitis through selection on somatic cell count. Vet. Clin. North Am. Food Anim. Pract. 9:563-581.

Stone, W. C., L. E. Chase, T. R. Overton, and K. E. Nestor. 2012. Brown midrib corn silage fed during the peripartal period increased intake and resulted in a persistent increase in milk solids yield of Holstein cows. J. Dairy Sci. 95:6665-6676.

Taylor, C. C., and M. S. Allen. 2005a. Corn grain endosperm type and brown midrib 3 corn silage: Feeding behavior and milk yield of lactating cows. J. Dairy Sci. 88:1425-1433.

Taylor, C. C., and M. S. Allen. 2005b. Corn grain endosperm type and brown midrib 3 corn silage: Site of digestion and ruminal digestion kinetics in lactating cows. J. Dairy Sci. 88:1413-1424.

Tyrrell, H. F., and J. T. Reid. 1965. Prediction of the energy value of cow's milk. J. Dairy Sci. 48:1215-1223.

Van Soest, P. J., J. B. Robertson, and B. A. Lewis. 1991. Methods for dietary fiber, neutral detergent fiber, and nonstarch polysaccharides in relation to animal nutrition. J. Dairy Sci. 74:3583-3597.

Yang, W. Z., and K. A. Beauchemin. 2009. Increasing physically effective fiber content of dairy cow diets through forage proportion versus forage chop length: Chewing and ruminal pH. J. Dairy Sci. 92:1603-1615

Zi, X., L. Mao, H. Zhou, J. Tang, and Y. Cai. 2017. Dynamics of shearing force and its correlations with chemical compositions and in vitro dry matter digestibility of stylo (Stylosanthes guianensis) stem. Asian-australas. J. Anim. Sci. 30:1718-1723. 